\title{
Wáshington Delgado (1927-2003)
}

\author{
Carlos García-Bedoya M. \\ Departamento de Literatura
}

$\mathrm{E}^{1}$ 6 de septiembre nos dejó el maestro Wáshington Delgado. Su partida resulta aún más dolorosa porque se hallaba en plena actividad: dos semanas antes había pronunciado una amenísima conferencia en nuestra Facultad (reproducida más adelante en este número), y además dos libros suyos estaban prontos a entrar en circulación. General es el pesar que esta pérdida ha provocado en nuestra comunidad académica y en los medios intelectuales y artísticos, y es que Wáshington Delgado fue una persona muy querida, que gozaba de un aprecio unánime, lo cual es sin duda una rara virtud.

Como profesor, despertaba el entusiasmo de los estudiantes, era el profesor motivador por excelencia, y todos los que fueron sus alumnos podrían evocar multitud de anécdotas que confirman este aserto. Poseía el don de la elocuencia, una enorme facilidad expresiva que hacía de él, además de un profesor estimulante, un excelente conferencista y un eximio conversador. Por ello su magisterio se extendió fuera de las aulas, y fue constante en el estímulo generoso a los jóvenes.

Su obra en el campo de la crítica y la historia literaria es sin duda valiosa. Fue un gran conocedor y amante de la literatura española, desde el medioevo hasta la generación del 27, pasando por Cervantes. Ha aportado significativamente al estudio de la literatura peruana. De estos trabajos cabe destacar su Historia de la literatura republicana (1980), texto que merece reeditarse. Allí propone, entre otras, una tesis que pareció en su momento controversial y que no ganó consenso, pero sin embargo portaba una intuición valiosa. Señala Delgado un momento de fundación de la literatura republicana, de fundación de nuestra autonomía literaria, en el que agrupa a autores de distintas generaciones: Ricardo Palma, Manuel González Prada, José Santos Chocano. Con ellos, ya después 
de la guerra con Chile, nuestra literatura se emancipa de los modelos españoles (en esto hay una aproximación coincidente con la de Mariátegui): tenemos así la tradición palmista, el ensayo beligerante y la delicada poesía cosmopolita de González Prada, la poesía modernista y americanista de Chocano. Con estos autores además comienza a configurarse un «canon» literario nacional, son figuras que se constituyen en referentes indispensables de nuestra tradición. Fundación pues en tanto formación de una tradición literaria autónoma. Pero implícita en la propuesta de Delgado hay también una intuición que no desarrolló a plenitud, pero que se adelanta al concepto actual de campo literario: en esa etapa, que coincide con los años iniciales de la «República Aristocrática», se organiza en el Perú una esfera literaria relativamente autónoma, una vida literaria que se apoya en diversas instituciones (Academia de la Lengua, Universidad, revistas y periódicos, etc.), que dan un dinamismo a la actividad literaria y la configuran como ámbito especializado, más desligado de otras esferas sociales y culturales (filosofía, sociología, política).

Indudablemente la faceta más conocida de la actividad intelectual de Wáshington Delgado es su labor como poeta. Es una de las figuras más destacadas de esa notable promoción de poetas conocida como «generación del 50». Autor de numerosos e importantes poemarios, entre ellos Formas de la ausencia (1955), Días del corazón (1957), Para vivir mañana (1959), Parque (1965), Destierro por vida (1969), Historia de Artidoro (1994), y el casi póstumo Cuán impunemente se está uno muerto (2003, en este número se publican un par de poemas de esa obra). Su libro de 1970, Un mundo dividido, que reúne gran parte de su producción poética, perdurará sin duda como uno de los grandes hitos de la poesía peruana.

Delgado ha sido considerado uno de los poetas más representativos de su generación, de la visión escéptica de estos intelectuales marcados por la frustración de sus ilusiones juveniles (apertura democrática de Bustamante, dictadura posterior de Odría). Pero a esa atmósfera desencantada que atraviesa gran parte de la poesía de Delgado contribuye también el existencialismo francés (Sartre, Camus) que marca el clima intelectual de los años 50. Esa angustia ante el absurdo de una experiencia humana signada por catástrofes espantosas (segunda guerra mundial, dictaduras genocidas de Hitler y Stalin), ha dejado huella en la poesía de Wáshington Delgado. Otra faceta de la doctrina existencialista enton- 
ces en boga fue la teoría sartreana del compromiso del escritor. Ante el debate planteado, los poetas del 50 se dividieron inicialmente entre «sociales» (comprometidos) y «puros». Pero ya en la obra de varios autores del 50, en especial Wáshington Delgado, se va superando esa dicotomía forzada. Su poesía desnuda la alienación humana y se compromete con utopías solidarias. Pero es también una poesía de perfección formal, de escritura cuidada y variedad de recursos técnicos. Bajo la aparente sencillez del lenguaje, hay una sutil construcción del verso y un profundo conocimiento de la tradición poética. En su caso, en especial de la tradición hispana, sobre todo sus predilectos poetas del 27 (entre ellos Pedro Salinas). Pero hay también una apertura a otras tradiciones, siendo especialmente gravitante el impacto de Brecht. Se ha señalado que sin duda se debe a Delgado el influjo desmitificador de la ironía brechtiana en varios de los jóvenes poetas del 60 (Heraud, Hernández, Cisneros, Martos).

Poeta, estudioso y apasionado de la literatura, la trayectoria de Wáshington Delgado abunda en logros y realizaciones. Como profesor, cautivó audiencias en diversas universidades del Perú y del extranjero, pero su carrera docente se desarrolló principalmente en la Universidad de San Marcos, donde llegó a ser Decano de la Facultad de Letras (entre 1985 y 1988) y fue luego distinguido como Profesor Emérito. Fue también miembro de la Academia Peruana de la Lengua. Pero más allá de su brillante carrera profesional, destaca el carisma personal de Wáshington Delgado, el aprecio unánime que lo rodeó. Destaca en particular la dimensión ética ineludible en todas las facetas de su accionar: ante todo y por sobre todo, en el más preciso sentido de la palabra, Wáshington Delgado fue un hombre de bien. 